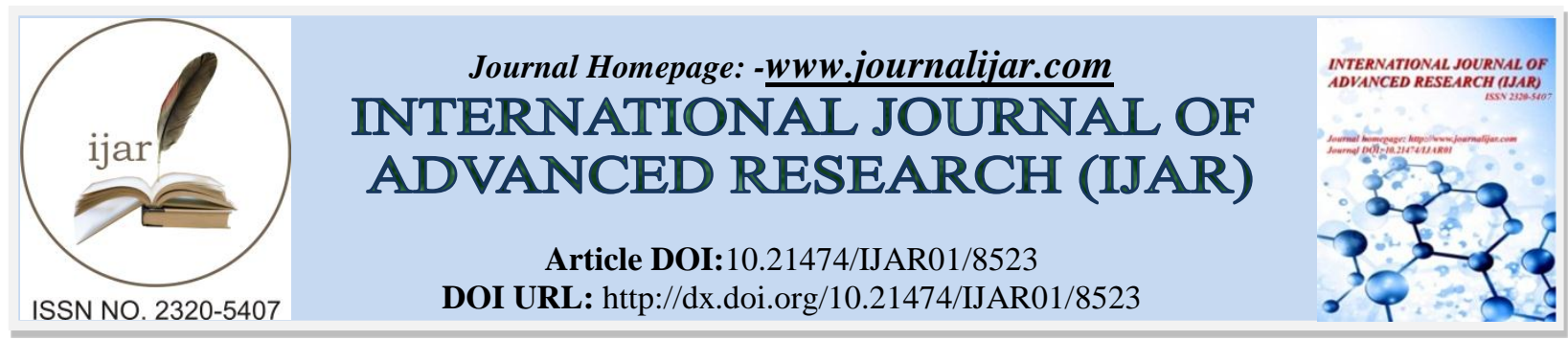

RESEARCH ARTICLE

\title{
TRANSMISSION MECHANISMS OF MONETARY POLICY IN ETHIOPIA: EVIDENCE FROM STRUCTURAL VAR APPROACH.
}

\author{
Abate Yesigat ${ }^{1}$, T.Koteswara Rao ${ }^{2}$ and G. Nagaraja ${ }^{3}$. \\ 1. Research scholar, Department of Economics, Andhra University, Visakhapatnam, India. \\ 2. Professor (retd), Department of Economics, Andhra University, Visakhapatnam, India. \\ 3. Professor, Department of Economics, Andhra University, Visakhapatnam, India.
}

\section{Manuscript Info}

\section{Manuscript History}

Received: 06 December 2018

Final Accepted: 08 January 2019

Published: February 2019

Key words:-

Ethiopia, Impulse response functions, monetary policy transmission mechanism, open economy, SVAR, variance decompositions.

\begin{abstract}
This study sought to examine the relative importance of the different monetary policy transmission channels and its effect on key macroeconomic variables using quarterly time series data covering from $1994 / 95 Q_{1}$ to $2017 / 18 Q_{4}$ in Ethiopia. Structural Vector Autoregressive model (SVAR) was used to address the issues. All the variables are tested for unit roots using ADF and PP test and model stability and other necessary tests was conducted. The estimation result indicates that the monetary aggregate, exchange rate and credit to the private sector are effective channels of monetary policy transmission in affecting output and inflation in Ethiopia, while the interest rate channel is weak. From a policy perspective, the results indicate that National Bank of Ethiopia is required to continuously monitor the developments of the monetary aggregate, the credit and foreign exchange markets in order to design effective monetary policies. In addition, it would help to the NBE to implement an effective monetary policy for achieving price and exchange rate stability and support sustainable economic growth through the appropriate monetary channels.
\end{abstract}

Copy Right, IJAR, 2019,. All rights reserved.

\section{Introduction:-}

Monetary policy is one of the most powerful and influential policy instruments available for an economy through which macro-economic and financial systems can be controlled. A carefully designed of monetary policy might assure sound economic and financial systems. On the other hand, a monetary policy that is constructed on less consideration of the factors that affect its effectiveness might have a counter effect. In order to run a healthy economy, therefore, it is crucial to understand how monetary policy works, through what mechanisms its policy actions are transmitted, what factors affect its transmission mechanisms, which channels are most effective and why they are effective. Studying the transmission channels contributes to the understanding of the effectiveness of channels as well as the way monetary shocks affect the economy. Dungey and Fry (2009) also conclude that understanding the effects of monetary shocks via monetary transmission channels will contribute to better management of the economy. 
Theoretically, the explanations of monetary policy transmission vary across various schools of thoughts and identify a number of different channels of transmission mechanism of monetary policy. According to classical quantity theory of money, monetary policy changes are transmitted directly into price movements. The monetarists led by the Milton Friedman posit that money matters and argue that monetary policy is transmitted through either interest rate, exchange rate channel or both. While for early Keynesians oppose the effectiveness of the monetary policy and held the belief that monetary policy works through bank lending and balance sheet channel. And again, for the intermediary school (Real business cycle) see money as neutral- that is they neither belief that money neither matters nor deny the effectiveness of monetary policy on the economy. However, they argue that there is reverse causation running from other important economic variables such as asset price to the supply of money (Meltzer, 1995).According to Mishkin (1995), the monetary policy transmission mechanism includes the interest rates, exchange rates, asset prices and the credit channels.

Though, extensive research on the transmission mechanism has also been conducted in developed countries, such work in developing countries, especially in Africa is lacking. This could be due to the fact that it was not long time ago, about the 1990s that countries in Africa started adopting the modem central bank operations in a market-based economic and financial system characterized by indirect monetary policy. Furthermore, there is also lack of consensus in the previous empirical findings. Bank lending channel seems to command popularity in most advanced countries of the world (Morsink and Bayoumi, 2001; and Elbourne, 2008). However, for developing and the low income countries the empirical evidences are mixed and full of contradictions (Mugume et al., 2011; Mengesha and Holmes, 2013; Davoodi et al., 2013; Abradu-otoo et al., 2013; Chileshe et al., 2014; Thi and Vinh, 2015;Mishra and Montiel ,2012 and Ghazanchyan, 2014). For instance, Tang (2006) found interest rate channel as a most important channel in Malaysia. Aleem (2010) found strong evidence for credit channel in India, Davoodi et al. (2013) found credit channel for East African countries, Mengesha and Holmes (2013) found bank lending channel as relevant in Eritrea, Perera and Wickramanayake (2013) the bank lending channels in Sri Lanka and others.

Despite the accessibility of studies both for developing and developed countries, the literature in Ethiopia is limited. Alemayehu (2011) tried to examine the monetary policy transmission mechanism in Ethiopia using VAR approach using quarterly data from 1970Q3 to 2004Q2 and found that monetary aggregate and credit channels as the best channel and exchange rate channel not work in Ethiopia.Whereas, Nuru (2009) using the same methodology and quarterly data from 1998Q3 to 2010Q2 found effective direct monetary aggregate and exchange rate channels, weak credit channel and inactive interest rate channel. This indicates, inconsistency in terms of the findings they have. Moreover, the existing studies of the Ethiopia monetary policy transmission mechanism include only domestic monetary policy and non-policy variables in their VAR approach. However, since a small open economy is likely to be quite sensitive to a variety of foreign variables, we included in our model foreign variables also. Moreover, to the author's best knowledge, so far there has been no empirical study in Ethiopia that linked foreign shocks, monetary policy, and domestic macroeconomics fluctuations by using an open economy SVAR framework. In this way, our study differs from past empirical studies that investigate the transmission mechanism of Ethiopian monetary policy. The remainder of this paper is organized as follows. Section 2 presents the financial sector and monetary policy development in Ethiopia. Section 3 provides the SVAR methodology used in the study while Section 4 provides the empirical results and interpretations. Finally, section 5 provides conclusion and policy recommendation.

\section{Financial sector and Monetary Policy development in Ethiopia}

Similar to other sub Saharan African countries, the monetary framework of Ethiopia are highly shaped by the type of government regime that came to power. The history of monetary policy dates back to 1943 when the State Bank of Ethiopia was established. Modern banking in Ethiopia started in 1905 with the establishment Bank of Abyssinian and in 1943 the Ethiopian government established the State Bank of Ethiopia. The Bank of Ethiopia was operating as both a commercial and a central bank until 1963 when it was changed into today's National Bank of Ethiopia and the Commercial Bank of Ethiopia. The practice of monetary policy in Ethiopia was believed to set in 1963, during the monarchial regime, when the National Bank of Ethiopia (NBE) established by proclamation 206 of 1963 by which the bank formally entitled administrative autonomy and juridical personality. Following, the overthrow of the Imperial regime, the country fall under the rule of communist regime (1974-1991). Then, the monetary variables were under the strict command of the central bank, where interest rates were fixed so as to restrict the private sector participation in the economy. Following the 1991 change of government, the country has experienced radical shift in the sphere of political economy. Monetary and Banking Proclamation of 1994 established the Monetary Authority as a judicial entity, separated from the governments and allowed private banks and insurance companies and other financial institutions to operate in the industry. Monetary and Banking proclamation No 83/1994 and the Licensing 
and Supervision of Banking Business No. 84/1994 laid down the legal basis for investment in the banking sector (Alemayehu, 2006).

Currently, the Central Bank is working towards achieving three fundamental objectives such as; to maintaining price and exchange rate stability, to foster a sound financial system and to undertake such other function as are conducive to the economic growth of Ethiopia. The monetary policy framework of the country involves three targets. Ultimate Target- maintain price and exchange rate stability, and support economic growth of the country; Intermediate Target-ensuring the money supply growth in line with nominal GDP growth rate" and Operational Target-the growth of base money, which is also known as reserve money, is used as operational target(NBE,2009). Currently, NBE is employing various monetary policy instruments in combination to achieve its objectives. Basically, these monetary policy instruments of NBE include; Open Market Operation (OMO), Standing central bank credit facility, reserve requirements, setting floor deposit rates, direct inter-bank borrowing or lending mechanism, credit control and moral suasion The bank uses these instruments either separately or in combination based on its policy target to be achieved(NBE, 2009).

The Ethiopian financial sector mainly consists of banks, insurance companies, microfinance institutions and, more recently, leasing companies. The financial sector is mainly dominated by the banking industry, which accounts for $76 \%$ of the total capital of the sector, followed by MFIs with 15\%. The remaining 9\% is held by insurance and leasing companies. The major formal financial institutions operating in Ethiopia are banks, insurance companies and microfinance institutions. Currently, there are 18 banks operating in the country, of which 16 are private banks while the remaining 2 are state owned banks, namely Commercial Bank of Ethiopia (CBE) and Development Bank of Ethiopia (DBE). The total number of bank branches in the sector reached 4,257 in 2017/18. As a result, bank branch to population ratio declined from 1:22,164 people in 2016/17 to 1:20,286.5 people in 2017/18. About 35.3 percent of bank branches were located in Addis Ababa, is the largest city in the country and seat of the Federal Government (the House of Representatives and the House of Federation), and the country's center of commerce and industry. It is also seat to the African Union (AU) and to the United Nations Economic Commission for Africa (ECA). Several other international organizations have their headquarters and offices in Addis Ababa.

According to the National Bank of Ethiopia (2017/18) there were 17 insurance companies with a total of 352 branches operating in the country. In terms of ownership, all insurance companies except the Ethiopian Insurance Corporation (EIC), are privately owned. Private insurance companies accounted for 84 percent of the total capital, while the remaining share was taken up by the single public owned enterprise, the Ethiopian Insurance Corporation. Of the total insurance branches, 53.6 percent are concentrated in Addis Ababa. And as of June 2017, 35 microfinance institutions licensed by the National Bank of Ethiopia succeeded in reaching more than 2.3 million clients and delivered about 7 billion Birr in loans. They also mobilized about 3.8 billion Birr of savings.

\section{Indicators of Financial Sector Development}

Financial reform is anticipated to expand the efficiency of the financial system in inducing individuals to hold more assets in financial form. The commonly used measurement of financial development/deepening is broad money (M2), which includes currency outside the banking sector, demand deposits held in local currencies, and savings accounts held in local currency. The figure below shows currency outside the banking sector as a proportion of gross domestic product (CoB/GDP), the narrow money as a ratio of GDP (M1/GDP), the broad money expressed as a ratio of gross domestic products (M2/GDP), demand deposit to gross domestic products(DD/GDP) and private sector credit to gross domestic products(PSC/GDP).

The result indicates that, during the study period (1994/5 to 2017/18), the ratio of M2 to GDP has grown fast from a relatively low initial level during 1994/95 to higher level. The figure also indicates that, the ratio of demand deposit to GDP has increased from 7.63 per cent during 1994/95 to 12.62 per cent during 2016/17 and quasi money to GDP ratio from 8.77 per cent to 16.02 per cent in the same period as can be seen in the figure below. 
Table 1:-Financial sector development indicators

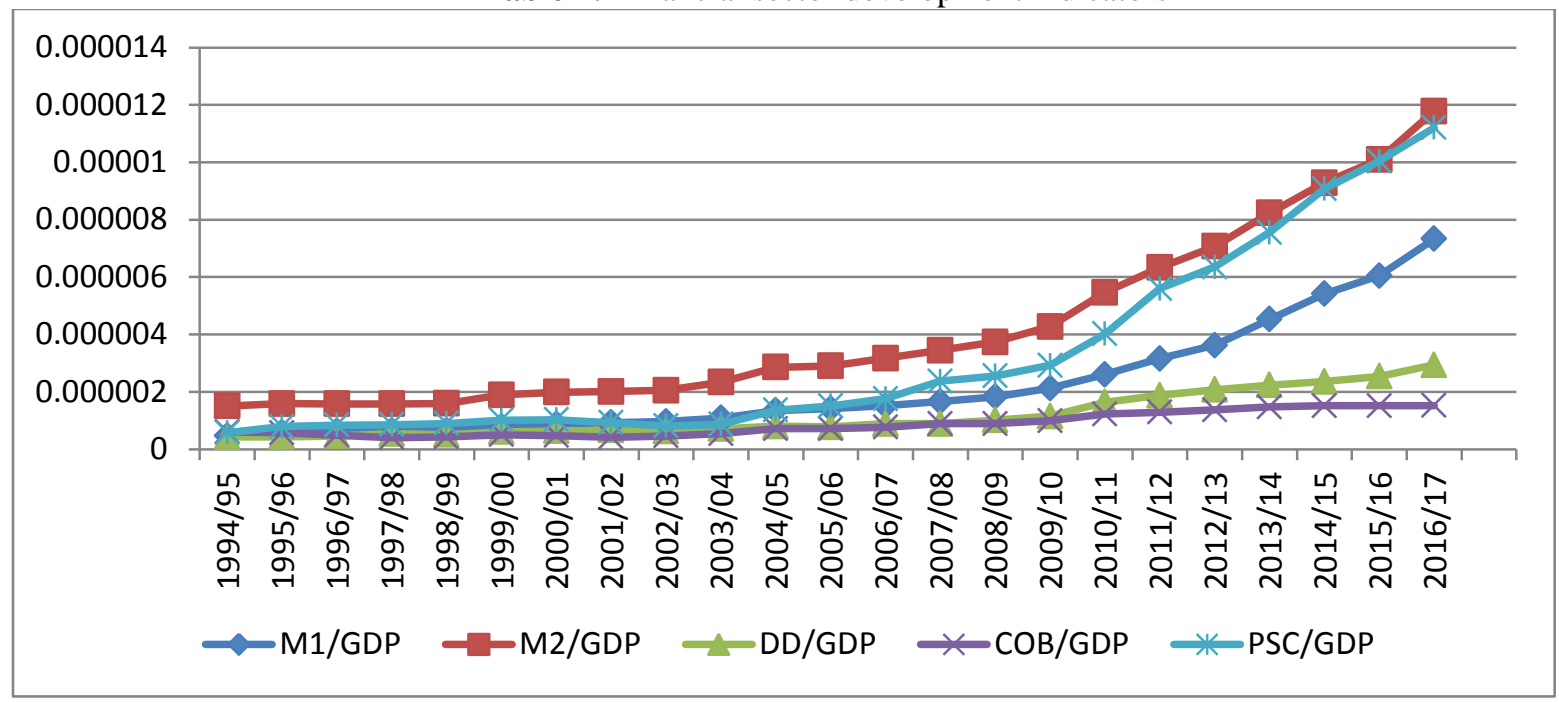

Source: computed based on NBE data

\section{Income velocity of money}

Velocity of money, i.e., the ratio of nominal income to the stock of money, lies at the heart of the relationship between money, income and price and assumes crucial importance in monetary policy formulation. The income velocity of money (VM) also plays the important role in ensuring the effectiveness of the monetary policy since when VM is unpredictable, money demand function is also unstable. Figure 2 show the income velocity of money for both M1 and M2 of Ethiopia for the period of 1994/95 to 2017/18. The velocity of both M1 and M2 in nominal terms has been declining gradually. The velocity of the VM1 has been more fluctuating than the VM2 in the study period. It is clear from the figures presented above that the VM2 seem to be relatively more stable than VM1.The declining value of VM of Ethiopia implies the increase in the degree of the monetization of the economy. The fall in the income velocity of broad money is due to the faster growth of broad money in comparison to that of the narrow money in the economy, with the growth in financial transactions, advancement in loans distribution techniques, financial innovation and service automation among others, the velocity of money would have undergone significant changes

Figure 2:-Income velocity of narrow (MV1) and broad money (MV2)

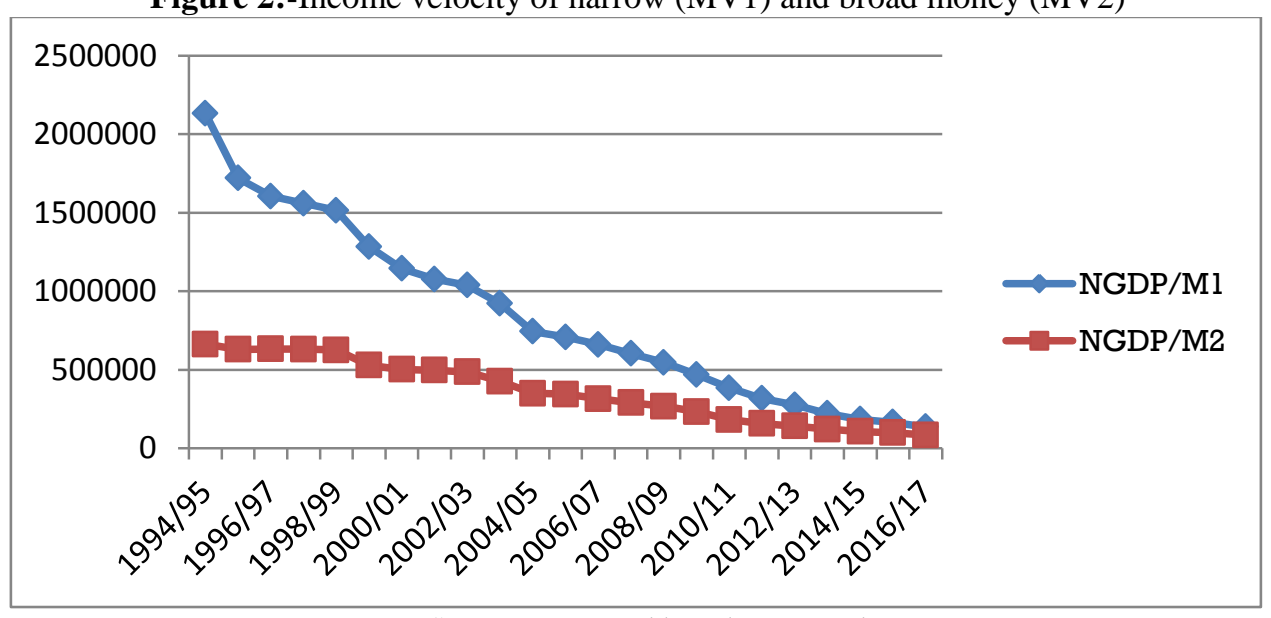

Source: computed based on NBE data

\section{Money Liquidity Ratio (M1/M2)}

The ratio of M1/M2 is also another indicator for financial development. That is a decline in the ratio implies a higher degree of diversification of financial institutions, as well as a greater availability or use of bank deposits as a medium of exchange. The development in this ratio indicates a greater accessibility and ease of use of non-currency 
forms of transaction media and a higher diversification of financial institutions. Figure 3 indicates M1/M2 has decreased as financial innovation has progressed in Ethiopia since liberalization.

Figure 3:-Money Liquidity ratio (M1/M2)

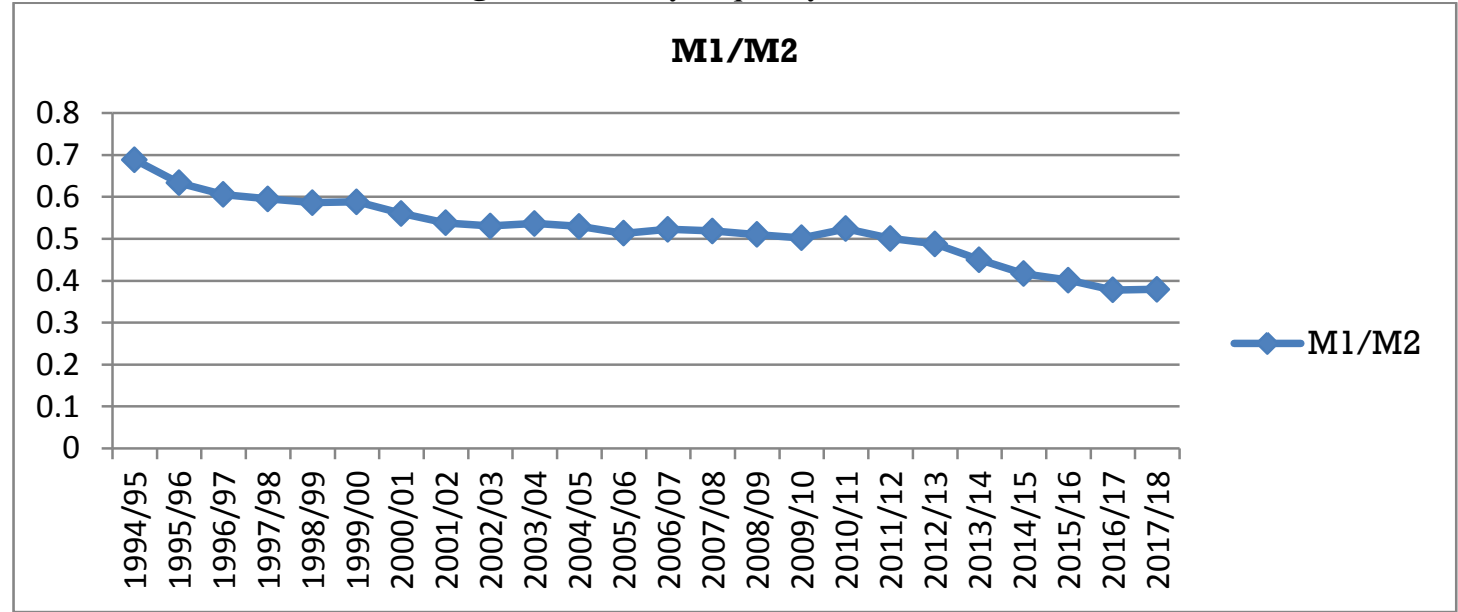

Source: computed based on NBE data

\section{Data and Research Methodology:-}

\section{SVAR Model of the Monetary Policy Transmission}

In this paper, the authors choose to estimate a SVAR model with contemporaneous restrictions to analyze the monetary transmission mechanism in the case of Ethiopia as pioneered by Sims (1986) and Bernanke (1986). It is useful to examine the relationship between forecast errors and structural innovations in an n-variable VAR. In a modeling sense, an SVAR has the following general form:

$$
\mathrm{A}_{0} \mathrm{Y}_{\mathrm{t}}=\mathrm{A}_{1}(\mathrm{~L}) \mathrm{y}_{\mathrm{t}}+\mathrm{B} \varepsilon_{t}-----------1
$$

Where: $Y_{t}$ is a $(n \times 1)$ vector of endogenous variables; $A_{0}$ and $B$ are vector of parameters, $A_{1}(L)=\sum_{i=1}^{n} A 1_{i} L_{I}$ is a matrix polynomial in the lag operator and $\left(\varepsilon_{t}\right)$ is a $(n \times 1)$ vector of vector of structural shocks. A SVAR model is put into a reduced VAR form by multiplying both sides of (1) by the inverse matrix $A_{0}^{-1}$

$$
\mathrm{Y}_{\mathrm{t}}=\mathrm{C}(\mathrm{L}) \mathrm{Y}_{\mathrm{t}}+e_{t}---------------2
$$

Where: $\mathrm{C}(\mathrm{L})=A_{0}{ }^{-1} A_{1}(\mathrm{~L})$ and $e_{t}$ represents a vector of reduced-form residual, that is $\mathrm{A}_{0}^{-1} B \varepsilon_{t}$ Thestructural form or compact form, an SVAR system relates to thefollowing relations:

$$
A_{o} e_{t}=B \varepsilon_{t}------------------3
$$

Equation (3) is known as the $\mathrm{AB}$ model (Amisano and Giannini, 1997). Where: $A_{0}$, is $(n \times n)$ matrix of contemporaneous relations between endogenous variables, $B$ is $(n \times n)$ matrix that linearly relates the SVAR residuals to the structural innovations, $e_{t}$ is vector of reduced-form residual, and $\varepsilon_{t}$ is vector of structural shocks. The residual $e_{t}$ in the reduced form is presumed to be white noise. Therefore, we can estimate the AB model by OLS (Ordinary Least Squares). The restrictions imposed on the $A_{0}$ matrix should come from the results of reliable empirical macroeconomic models and based on the theory. The more common approach in this regard is to impose a set of identification restrictions that are broadly consistent with economic theory that expects to provide sensible outcomes. Kim and Roubini (2000) created a template of identification in SVAR while evaluating the monetary policy of OECD economies and it later became the standard approach in modeling the monetary policy framework for a small open economy, and then applied by Rokon (2008) in Canada, Raghavan et al. (2012) in Malaysia, and Thanabalasingam (2013) in Sri Lanka and others. 
Based on the reviewed theoretical and empirical literatures, eight-variable non-recursive identifications SVAR model has been established to investigate the monetary policy transmission channel in Ethiopia. Non-recursive identification, which contains one or more 'feedback loops' or 'reciprocal' effects is more flexible and more appropriate for modeling the economy.

$$
Y t=\left[\mathrm{WOP}_{\mathrm{t}}, \mathrm{FFR}_{\mathrm{t}}, \mathrm{RGDP}_{\mathrm{t}}, \mathrm{CPI}_{\mathrm{t}}, \mathrm{M}_{\mathrm{t}}, \mathrm{TB}_{\mathrm{t}}, \mathrm{PSC}_{\mathrm{t}}, \mathrm{NEER}_{\mathrm{t}}\right]-----4
$$

There were two international variables and six domestic variables in the above equation. World oil price (wop) and the federal fund rate (ffr) accounted for external shocks or international variables, in which oil was the non-policy external inflationary pressure and the fed was the proxy for external foreign monetary policy pressure. Domestic variables included real gross domestic product (rgdp) and consumer price index (cpi), which were the targets of monetary policy; money supply $\left(\mathrm{m}_{1}\right)$ and the policy interest rate (in this case treasury bill rate), which were considered monetary policy instruments; and the nominal effective exchange rate (neer), which accounted for the market information force.

$$
\left[\begin{array}{cccccccc}
1 & 0 & 0 & 0 & 0 & 0 & 0 & 0 \\
a_{21} & 1 & 0 & 0 & 0 & 0 & 0 & 0 \\
a_{31} & 0 & 1 & 0 & 0 & 0 & 0 & 0 \\
a_{41} & 0 & a_{43} & 1 & 0 & 0 & 0 & 0 \\
0 & 0 & a_{53} & a_{54} & 1 & a_{56} & 0 & 0 \\
0 & a_{62} & a_{63} & a_{64} & 0 & 1 & 0 & 0 \\
0 & 0 & 0 & a_{74} & a_{75} & a_{76} & 1 & 0 \\
a_{81} & a_{82} & a_{83} & a_{84} & a_{85} & a_{86} & 0 & 1
\end{array}\right]\left[\begin{array}{c}
\mu_{\text {wop }} \\
\mu_{f f r} \\
\mu_{r g d p} \\
\mu_{c p i} \\
\mu_{m 1} \\
\mu_{t b} \\
\mu_{p s c} \\
\mu_{\text {neer }}
\end{array}\right]=\left[\begin{array}{cccccccc}
b_{11} & 0 & 0 & 0 & 0 & 0 & 0 & 0 \\
0 & b_{22} & 0 & 0 & 0 & 0 & 0 & 0 \\
0 & 0 & b_{33} & 0 & 0 & 0 & 0 & 0 \\
0 & 0 & 0 & b_{44} & 0 & 0 & 0 & 0 \\
0 & 0 & 0 & 0 & b_{55} & 0 & 0 & 0 \\
0 & 0 & 0 & 0 & 0 & b_{66} & 0 & 0 \\
0 & 0 & 0 & 0 & 0 & 0 & b_{77} & 0 \\
0 & 0 & 0 & 0 & 0 & 0 & 0 & b_{88}
\end{array}\right]\left[\begin{array}{c}
\varepsilon_{\text {wop }} \\
\varepsilon_{f f r} \\
\varepsilon_{r g d p} \\
\varepsilon_{c p i} \\
\varepsilon_{m 1} \\
\varepsilon_{t b} \\
\varepsilon_{p s c} \\
\varepsilon_{\text {neer }}
\end{array}\right]-5
$$

Where $\varepsilon w o p, \varepsilon f f r, \varepsilon r g d p, \varepsilon c p i, \varepsilon m 1, \varepsilon t b, \varepsilon p s c$, $\varepsilon$ neer respectively are the structural innovations of the shocks from the world oil price, federal fund rate, real gross domestic product, consumer price index, money supply, policy interest rate, private credit supply, and nominal effective exchange rate.

It is noticeable that vector Ytconsists of three different blocks of variables that have inter-linkages with each other, which are , the foreign block (wop, ffr), representing the exogenous shocks from international economy, the nonpolicy block (rgdp, cpi), describing the goods market equilibrium, and the policy block, (m1, tbpsc, neer) describing the money market equilibrium.

The inclusion of foreign variables was essential for correct model specification, improved identification of contemporaneous relationships, and to capture the underlying impulse responses of variables to various shocks. In addition, Ethiopia is oil importer and the assumption that oilmight exert an effect on all other variables contemporaneously. The inclusion of the fed fund rate is to account for the impact from international monetary policy. In addition, the fed is assumed to be contemporaneously correlated with oil because the Federal Reserve needs to adjust their policy immediately whenever there is a shock to the international oil price. Certainly, the shocks originating from Ethiopia are unlikely to have any significant impact on the rest of the world, since Ethiopia is small open economy, thus oil and fed are not contemporaneously affected by domestic variables of Ethiopia, those exogenous (Raghavan\&Silvapulle, 2012).

Non-policy block (RGDP, CPI): these are the targeted economic variables, which are assumed to receive contemporaneous influence from foreign variables and lagged impacts from other domestic variables. Specifically, GDP is influenced by oil, while CPI is impacted by both oil and fed fund rate. The rationality behind this assumption is that domestic firms must respond immediately to oil price shocks due to the important role of oil in all sectors. However, they are unlikely to adjust outputs and prices within a month in response to unexpected shocks from domestic monetary policies. Moreover, Policy block ( $\mathrm{m} 1$, interest, credit, exrate): This block consists of NBE's regular monetary instruments, which are money supply $\left(\mathrm{M}_{1}\right)$, policy interest rate, which is proxied by T-bill rate, credit supply to the private sector, and nominal effective exchange rate. 
Furthermore, in the identification, it is assumed that GDP, CPI, and interest contemporaneously impact $\mathrm{m}_{1}$, meaning that while adjusting for the current level of money supply, the NBE also monitors the growth level of output and price level, as well as other monetary indicators. Interest is assumed to be affected by FFR, GDP, and CPI contemporaneously. That is NBE adjusts the refinancing rate based on the international interest rate level and other domestic targeted variables. Credit is assumed to not be influenced by foreign variables but is impacted by all domestic variables, except GDP. However, this model had to ignore the asset price channel due to the lack of data and the fact that the financial asset market in Ethiopia is in its infancy stage.

\section{Source and Types of Data}

World oil price and federal fund rate data were obtained from World Bank database. Whereas, domestic variables data were obtained from Ministry of Finance and Economic Cooperation (MoFEC) and National Bank of Ethiopia (NBE) and the study employed a quarterly data which covers a period from 1994/95Q1 to 2017/18Q4. All the variables were transformed to natural logs with the exception of Treasury bill and federal fed rate, which are in percentage. Since GDP data available only in annual series an interpolated to quarterly data using the quadratic-sum approach of E-views 10 software was applied.

\section{Results and Discussion:-}

\section{The Unit Root Test for Stationary}

The well-known Augmented Dickey- Fuller (1981) and the Phillips Perron (1988) unit root tests were applied to test the existence of unit root.Otherwise, estimating relationships with non-stationary variables results in spurious regression (Gujarati, 2004 and Wooldridge, 2004).The unit root test is undertaken both at the intercept and intercept plus trend regression forms, and the results of the test for the variables at level and first difference using ADF and PP test are presented in table 1.

Table 1:-unit root test

Source: Author's estimation

\begin{tabular}{|c|c|c|c|c|c|c|c|c|}
\hline \multicolumn{9}{|c|}{ Phillips-Perron test statistic (ADF Test) } \\
\hline & \multicolumn{4}{|c|}{ With Intercept } & \multicolumn{4}{|c|}{ Trend and Intercept } \\
\hline & \multicolumn{2}{|l|}{ ADF } & \multicolumn{2}{|l|}{$\mathrm{PP}$} & \multicolumn{2}{|l|}{ ADF } & \multicolumn{2}{|l|}{$\mathrm{PP}$} \\
\hline variables & level & $\begin{array}{l}1^{\text {st }} \\
\text { difference }\end{array}$ & level & $\begin{array}{l}\text { 1st } \\
\text { difference }\end{array}$ & level & $\begin{array}{l}\text { st } \\
\text { difference }\end{array}$ & level & $\begin{array}{l}\text { st } \\
\text { difference }\end{array}$ \\
\hline LWOP & -1.599 & $-7.402 * * *$ & -1.625 & $-7.25 * * *$ & -2.020 & $-7.405 * * *$ & -1.251 & $-7.207 * * *$ \\
\hline FFR & -1.997 & $-4.256 * * *$ & -1.398 & $-4.33 * * *$ & $3.830 * *$ & $-4.205 * * *$ & -2.936 & $-4.279 * *$ \\
\hline LRGDP & $2.650 *$ & -1.564 & 1.480 & $-4.99 * * *$ & 0.367 & -2.937 & 0.923 & $-5.15 * * *$ \\
\hline LCPI & 1.433 & $-7.964 * * *$ & 1.252 & $-7.96 * * *$ & -1.936 & $-8.294 * * *$ & -1.938 & $-8.294 * * *$ \\
\hline LM1 & $2.7837^{*}$ & -1.790 & $4.71 * * *$ & $-7.73 * * *$ & -1.983 & $-4.074 * * *$ & -0.534 & $-9.958 * * *$ \\
\hline TB & -2.429 & $-4.389 * * *$ & -1.329 & $-4.42 * * *$ & -1.813 & $-4.607 * * *$ & -1.101 & $-4.582 * * *$ \\
\hline LPSC & 0.328 & $-3.116^{* *}$ & 1.008 & $-4.07 * * *$ & -2.198 & $-3.349 * *$ & -0.918 & $-4.416 * * *$ \\
\hline LNEER & -1.248 & $-9.055^{*} * *$ & -1.377 & $-9.05 * * *$ & -0.959 & $-9.134 * * *$ & -1.073 & $-9.134 * * *$ \\
\hline
\end{tabular}

Note: $*, * *, * * *$ indicates significant level at $10 \%, 5 \%$ and $1 \%$ level of significance With Critical values with constant but no trend 3.504, 2.893 and 2.584 and Critical values with constant and trend 4.063, 3.460 and 3.156 respectively.

\section{Lag length and VAR Stability Check}

To determine the lag length of the reduced form (VAR), the study uses different lag-length selection criteria, including LR, FPE, AIC, SC, and HQ. In Table 2 the lag length selection criterion is tabulated. The entire lag length section test suggests appropriate lag length for the VAR model is one (1).

Table 2:-VAR Lag Order Selection Criteria

\begin{tabular}{|c|c|c|c|c|c|c|}
\hline Lag & LogL & LR & FPE & AIC & SC & HQ \\
\hline 0 & 2749.931 & NA & $7.42 \mathrm{e}-39$ & -65.09360 & -64.63059 & -64.90747 \\
\hline 1 & 3184.394 & $765.4827^{*}$ & $1.11 \mathrm{e}-42^{*}$ & $-73.91415^{*}$ & $-71.59909^{*}$ & $-72.98351^{*}$ \\
\hline 2 & 3131.650 & -82.88381 & $1.86 \mathrm{e}-41$ & -71.13452 & -66.96741 & -69.45938 \\
\hline 3 & 3157.089 & 35.12995 & $5.23 \mathrm{e}-41$ & -70.21640 & -64.19724 & -67.79675 \\
\hline 4 & 3208.027 & 60.63999 & $8.94 \mathrm{e}-41$ & -69.90539 & -62.03418 & -66.74123 \\
\hline
\end{tabular}




\begin{tabular}{|l|l|l|l|l|l|l|}
\hline 5 & 3287.544 & 79.51704 & $9.18 \mathrm{e}-41$ & -70.27485 & -60.55158 & -66.36618 \\
\hline 6 & 3352.971 & 52.96502 & $1.72 \mathrm{e}-40$ & -70.30883 & -58.73351 & -65.65565 \\
\hline 7 & 3431.318 & 48.50085 & $3.61 \mathrm{e}-40$ & -70.65044 & -57.22307 & -65.25275 \\
\hline 8 & 3547.682 & 49.86991 & $6.65 \mathrm{e}-40$ & -71.89718 & -56.61776 & -65.75498 \\
\hline
\end{tabular}

Source: Author's estimation

Before using the optimal lag length to estimate the parameters of the SVAR, it is necessary to check the conditions of VAR stability using the AR roots. The results, presented in table 3, show that all the eigenvalues in the proposed model lay in the unit circle, that is there value less than one or unity. So the VAR/SVAR model satisfies the stability condition.

Table 3:-Roots of Characteristic Polynomial

\begin{tabular}{|l|l|}
\hline Root & Modulus \\
\hline 0.999691 & 0.999691 \\
\hline $0.969908-0.142463 \mathrm{i}$ & 0.980315 \\
\hline $0.969908+0.142463 \mathrm{i}$ & 0.980315 \\
\hline $0.931473-0.053298 \mathrm{i}$ & 0.932997 \\
\hline $0.931473+0.053298 \mathrm{i}$ & 0.932997 \\
\hline $0.749619-0.290893 \mathrm{i}$ & 0.804082 \\
\hline $0.749619+0.290893 \mathrm{i}$ & 0.804082 \\
\hline 0.784373 & 0.784373 \\
\hline $0.630800-0.421556 \mathrm{i}$ & 0.758695 \\
\hline $0.630800+0.421556 \mathrm{i}$ & 0.758695 \\
\hline $0.614054-0.166841 \mathrm{i}$ & 0.636316 \\
\hline $0.614054+0.166841 \mathrm{i}$ & 0.636316 \\
\hline $0.094623-0.204394 \mathrm{i}$ & 0.225234 \\
\hline $0.094623+0.204394 \mathrm{i}$ & 0.225234 \\
\hline$-0.039197-0.024575 \mathrm{i}$ & 0.046263 \\
\hline$-0.039197+0.024575 \mathrm{i}$ & 0.046263 \\
\hline No root lies outside the unit circle. & \\
\hline VAR satisfies the stability condition. & \\
\hline Source Auth & \\
\hline
\end{tabular}

Source: Author's estimation

The model requires $2 n^{2}-n(n+1) / 2$ number of restrictions to be the SVAR model identified. sine in our case the number of variables are 8 and based on the above formula we need 92 restrictions for matrix $A$ and $B$ to be just identified. Of these, 56 restrictions are given by matrix B, since it is a diagonal matrix. Thus, 36 restrictions are required in $\mathrm{A}$ for the system to be just identified. The model specified in equation 5 is over identified with 111 restrictions, which are greater than 92. Moreover, the identifying restrictions were not rejected at the 5\% level (see table 4).The LR test for the over-identification restriction of the contemporaneous SVAR model finds the additional restrictions to be valid, with the probability value of 0.399 (see table 4 ). Thus, we need to check the over-identifying restriction test to test the validity of the identifying restrictions imposed in the model. That is likelihood ratio test does not reject the over-identified restrictions for Saudi Arabia. The Chi-square (8) test for Ethiopia is 8.354, with the corresponding $p$-value of 0.399 .

Table 4:-Estimation Results of Structural-VAR Model

Log likelihood 910.1109

LR test for over-identification:

Chi-square(8) 8.354498 Probability 0.3996

Source: Author's estimation

As mentioned earlier the aim of SVAR model analysis is not the parameter estimations but the dynamic response of impulse response and variance decomposition, because the estimated coefficient exhibits limited significance so the 
inference should rely on the dynamic interaction of the variables. The analysis of impulse response and variance decomposition to see the effects of monetary policy transmission channel on income and price are presented as follows.

\section{Estimation Results of Impulse Response Function}

This section explains the estimated impulse response function used to understand the dynamic responses of output and price to various domestic and foreign monetary policy shocks within the SVAR system. The estimated impulse responses of the variables, over a 20 quarter (four year) and to structural one-standard-deviation monetary policy shocks, are described. In the figure, each of the two dashed lines represents the $95 \%$ confidence band. The values on the vertical line represent the deviation from the baseline level of the variable in response to a given shock on the policy variable. The results on the horizontal line represent the time passed after the introduction of the shock.

Figure 4:-Responses of output for Domestic and Foreign Variables Shock

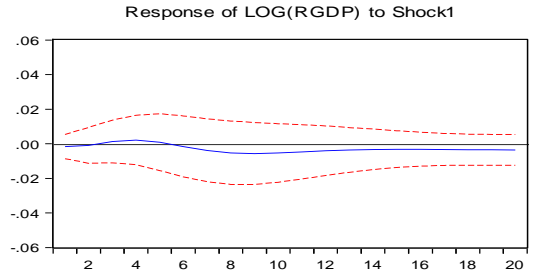

Response of LOG(RGDP) to Shock4

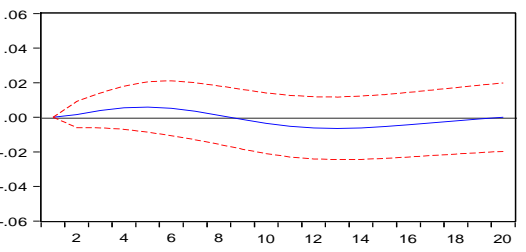

Response of LOG(RGDP) to Shock7

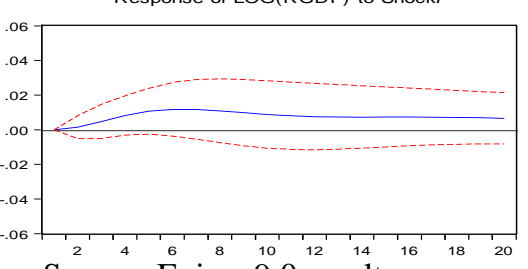

Source: Eview 9.0 results

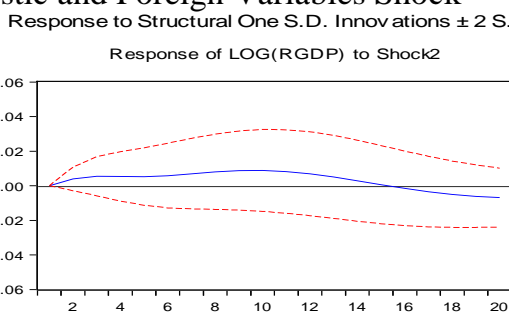

Response of LOG(RGDP) to Shock5

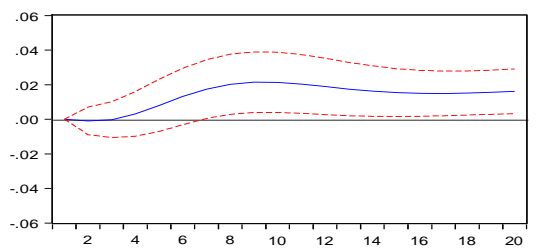

Response of LOG(RGDP) to Shock8

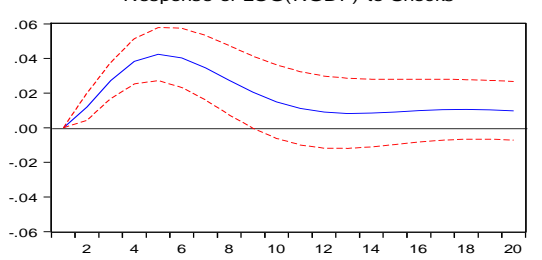

Response of LOG(RGDP) to Shock3

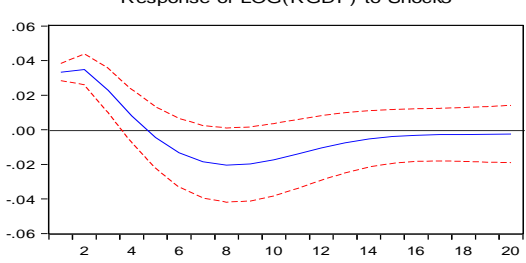

Response of LOG(RGDP) to Shock6

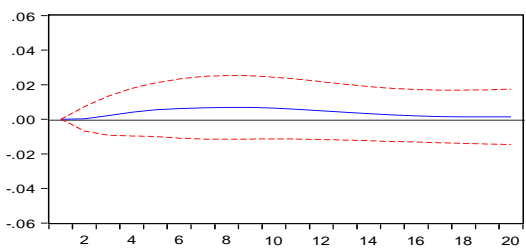

Figure 4 shows the responses of output to various shocks and Figure 5 shows the responses of price (CPI) to various foreign and domestic monetary variable shocks.

Shock1 in figure 4 and 5 shows the response of output and price level for world oil price shock (WOP). As expected, output decreases in response to WOP (shocks1). The increase in world oil price is expected to transfer to domestic economy through increase in price of exported commodity, which in turn affects domestic output and price. Negative responses of GDP and CPI explained by the rising cost of production due to an increase in world oil price, since Ethiopia is oil importing country and domestic petroleum price

Shock 2 in figure 4 indicates, output puzzle refers to an increase in output in response to a monetary policy tightening of increase in FFR and in figure 5, an increase in FFR have a negative impact on CPI. One possible explanation is an increase in FFR might decrease world oil price, and a decrease in oil price might cause inflation to fall in Ethiopia, since Ethiopian economy is depend on imported oil.

Shock5 in figure 4 and 5 shows the estimated impulse responses of output and price to positive money growth shocks, respectively. Output increase in response to a positive monetary shock and that monetary expansion is an important source of economic growth by reducing cost of investment and encouraging investment and then aggregate demand and economic growth, which is in line with the theory. The effect of a shock to M1 (Shock5) on prices is positive (as can be seen from figure 5). 
Shock6 in Figure 4 and 5 shows the effect of T-bill rate shock on output and price. A positive shock to T-bill rate has a positive impact one output at least in the shot and medium team, which indicates output puzzle occurred, but after this period its effect die out. And also appositive shock to the T-bill rate increases a price at most for two years which is also price puzzle, while beyond the two year period ( 8 quarter) the price is decreased continuously which indicated that it is statistically significant.

Figure 5:-Responses of price for Domestic and Foreign Variables Shock Response to Structural One S.D. Innov ations \pm 2 S.E.

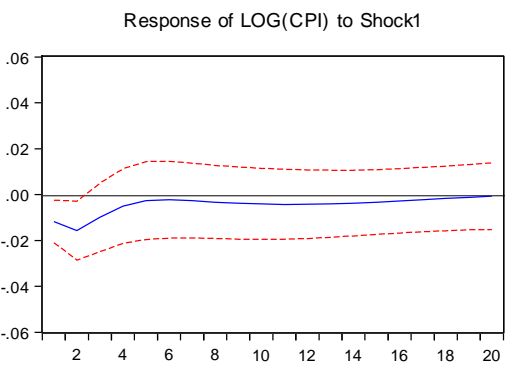

Response of $\mathrm{LOG}(\mathrm{CPI})$ to Shock2
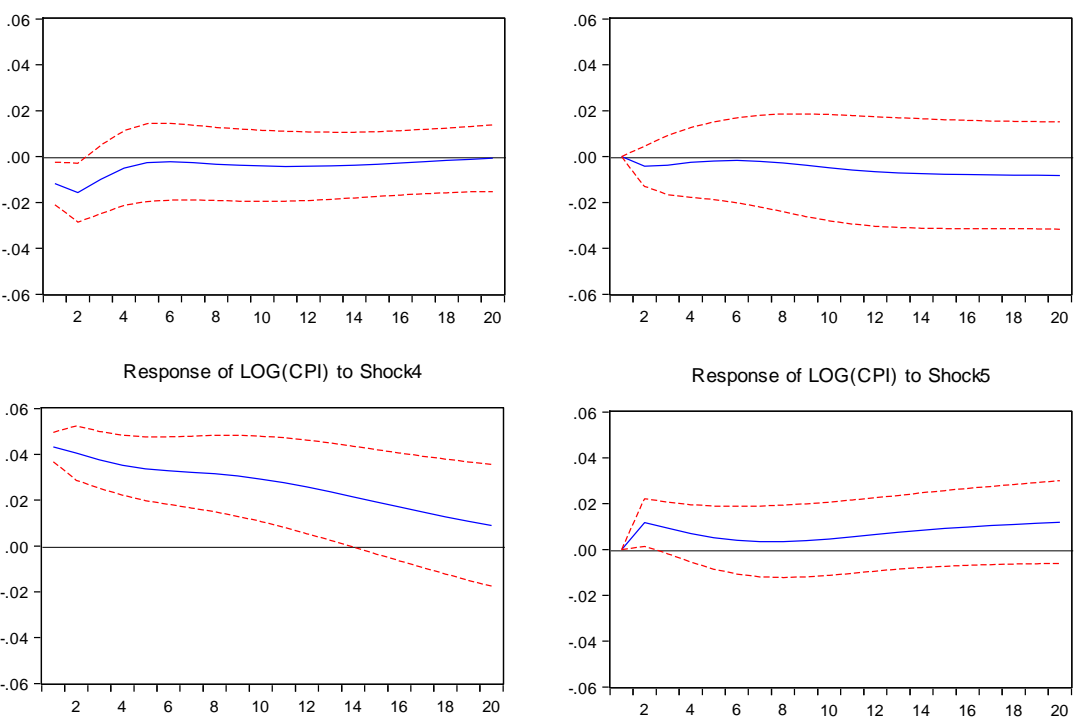

Response of LOG(CPI) to Shock7

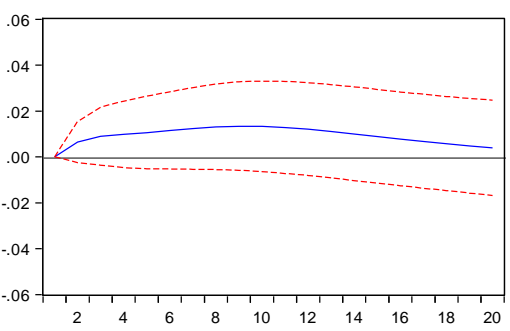

Response of LOG(CPI) to Shock5

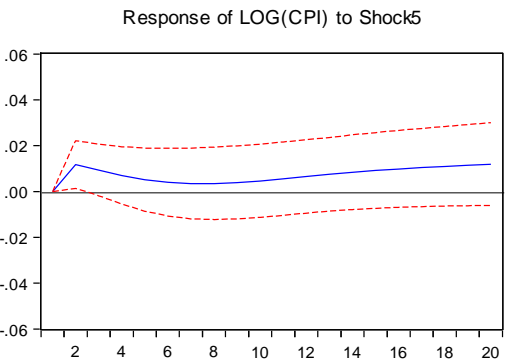

Response of LOG(CPI) to Shock8

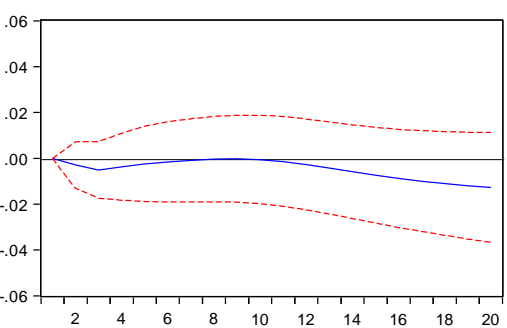

Response of LOG(CPI) to Shock3

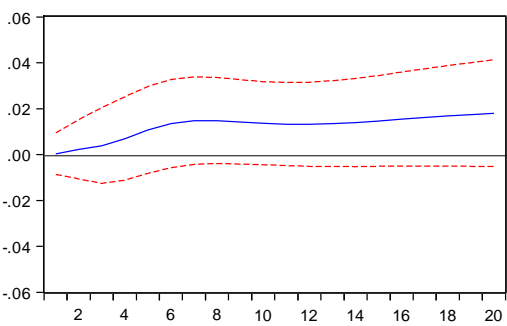

Response of LOG(CPI) to Shock6

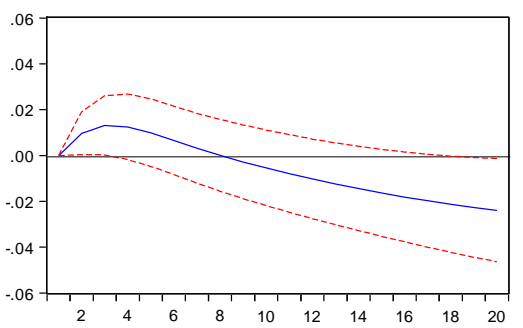

Source: Author's estimation

Shock 7 in Figure 4 and 5 indicates that Positive credit shock affects RGDP and CPI positively, which is in line with our expectations and the theories. That is the increases in credit create more demand for goods and services and hence increase the output and price level. These results show that there is an effective credit channel of monetary policy transmission.

Shock8 shows the responses of output to nominal effective exchange rate shock. Positive NEER shocks, representing an increase in nominal effective exchange (appreciation) increase real income (RGDP). Ethiopia is an import dependent country where its imports are mainly composed of capital goods and raw materials which a country cannot afford now. Thus, devaluation makes the price of these essential imported goods more expensive and thereby discouraging domestic investment activities which will affect output level.

\section{Estimation Results of Variance Decomposition Function}

Variance decomposition of output $(\mathrm{Q})$ and prices $(\mathrm{P})$ is carried out to look at the strengths of each channels of monetary transmission mechanism. This is achieved by using forecast horizons of 1 through 20 quarters. The first column lists the quarters ahead, whereas the second column refers to standard error (SE), which is the forecast error of the variable at different quarters. Shock represent each variables Shock: Shock1 (WOP), Shock2 (FFR), shock3 
(RGDP), shock4 (CPI), shock5 (m1), shock6 (TB), shock7 (PSC) and Shock8 (NEER).Moreover, The decomposition values for the $1^{\text {st }}, 4^{\text {th }}, 8^{\text {th }} 12^{\text {th }}, 16^{\text {th }}$, and $20^{\text {th }}$ horizon into the future are displayed in table 5 and 6.

The fluctuations of Y (output) are mainly explained by its own shocks (Shock 3), money supply (Shock 5) and NEER (shock8) over the short and medium period. In terms of transmission channels, nominal effective exchange rate shocks (Shock 8) explain more output fluctuations than credit shocks (Shock 7) and money supply shocks (Shock 6). The impacts of three channels (exchange rate, money supply and credit) are effective transmission channels of monetary policy in affecting output, while the influences of the interest rate channel is ineffective as can be seen its contribution in affecting output in table 5 . The contribution of world oil prices (Shock 1) and foreign interest rates (Shock 2) are small. It indicates, in both the short and medium period, internal factors play a crucial role in the fluctuations of output than foreign variables.

Table 5:-Variance Decomposition of RGDP

\begin{tabular}{|c|c|c|c|c|c|c|c|c|c|}
\hline Period & S.E. & Shock1 & Shock2 & Shock3 & Shock4 & Shock5 & Shock6 & Shock7 & Shock8 \\
\hline 1 & 0.1244 & 0.2599 & $3.97 \mathrm{E}-3$ & 99.740 & $3.23 \mathrm{E}-3$ & $2.09 \mathrm{E}-3$ & $1.49 \mathrm{E}-3$ & 0.0000 & $1.73 \mathrm{E}-2$ \\
\hline 4 & 0.2188 & 0.1818 & 1.3148 & 52.626 & 0.8728 & 0.1896 & 0.3772 & 1.6614 & 42.775 \\
\hline 8 & 0.3096 & 0.4096 & 1.7857 & 28.097 & 0.8897 & 6.9870 & 1.3083 & 4.3475 & 56.174 \\
\hline 12 & 0.3762 & 0.8670 & 2.8288 & 26.767 & 1.1034 & 14.569 & 1.7950 & 4.9074 & 47.161 \\
\hline 16 & 0.4242 & 1.0062 & 2.7395 & 24.770 & 1.6284 & 18.299 & 1.8041 & 5.5005 & 44.252 \\
\hline 20 & 0.4636 & 1.1479 & 3.0739 & 22.872 & 1.5676 & 21.168 & 1.6933 & 5.9348 & 42.541 \\
\hline
\end{tabular}

Table 6 below shows that the explanation of the CPI fluctuations varies in the short and medium run. In short run, its own shock (Shock 4) explains more variations in CPI than other shocks; the next factors are credit (Shock 7) and world oil price (Shock1). The impact of the world oil price on price level increases at longer horizons in the short run and remains a significant contribution, implying that the world oil price affects domestic price level with some lags. The explanation for CPI fluctuations from output shocks and its own shocks becomes more important as the horizons expand. An examination of the transmission channels shows that the money supply, credit channel and interest rate channels are effective, whereas exchange rate channel is ineffective in the short run, which is similar with the results of impulse response analysis.

Table 6:-Variance Decomposition of CPI

\begin{tabular}{|c|c|c|c|c|c|c|c|c|c|}
\hline Perid & S.E. & Shock1 & Shock2 & Shock3 & Shock4 & Shock5 & Shock6 & Shock7 & Shock8 \\
\hline 1 & 0.1244 & 6.9208 & 0.0000 & 0.0056 & 93.073 & 0.0000 & 0.0000 & 0.0000 & 0.0000 \\
\hline 4 & 0.2188 & 6.6210 & 0.5052 & 0.8737 & 79.573 & 3.5301 & 5.4488 & 2.8073 & 0.6399 \\
\hline 12 & 0.3762 & 3.2730 & 0.9343 & 8.2030 & 72.875 & 2.4121 & 4.1661 & 7.7643 & 0.3715 \\
\hline 16 & 0.4242 & 2.8401 & 1.7294 & 10.133 & 65.692 & 3.2495 & 7.4737 & 7.7857 & 1.0950 \\
\hline 20 & 0.4636 & 2.3639 & 2.3478 & 12.442 & 55.901 & 4.4339 & 12.959 & 6.7943 & 2.7560 \\
\hline
\end{tabular}

\section{Conclusions and Policy Recommendations:-}

This study examines the transmission mechanism of monetary policy in Ethiopia using quarterly time series data from 1994/95Q1 to 2017/18Q. Small open economy structural Vector Auto Regression (SVAR) model with two foreign and six domestic variables was used to examine the effectiveness of the different monetary transmission channel. All the variables are tested for unit roots using ADF and PP test and model stability and other necessary tests was conducted.

The results derived from Structural impulse response and structural variance decompositions derived from Structural VAR show that direct monetary transmission, credits to the private sector and nominal effective exchange rate have significant impacts on output and price level in Ethiopia indicating that monetary policy transmission channel is effective in influencing macroeconomic variables in the Ethiopian economy. However, the results of interest rate channel in affecting output and price is not effective relative to other channels.

It is, therefore, recommended that monetary authorities target monetary aggregate as a policy variable for effective monetary policy implementation, because the interest rate channel is ineffective. This implies that national Bank of Ethiopia is Effective in choosing intermediate monetary policy target. Moreover, since the credit channel is important mechanisms through which monetary policy is transmitted in Ethiopia, bringing the informal sector that extends credit into the formal system will increase the benefit to the economy by channeling fund to the more 
productive sector and key economic sectors which remain less financed by the banking sector. Furthermore, to make the interest rate channel effective the National bank of Ethiopia and other stakeholders will need to support the current trends in the development of financial markets to increase the participation of households and non-bank institutional investors in treasury bills of different maturities; substitution between bank lending and other types of external finance like equity or bond markets by developing capital markets.

\section{References:-}

1. AlemayehuGeda (2006). The structure and performance of Ethiopia's financial sector in the pre- and post-reform period with a special focus on banking' UNU-WIDER, United Nations University (UNU), Working Paper.

2. Amisano, G. and C. Giannini. 1997. Topics in Structural VAR Econometrics. Springer Berlin Heidelberg. Atchariyachanvanich, W. 2004. "VAR Analysis

3. Chileshe, P., Mbao, F. Z., Mwanza, B., Mwansa, L., \&Zgambo, P. (2014). Monetary Policy Transmission Mechanism in Zambia, 1-49.

4. Davoodi H. R., Dixit, S., and Pinter, G. (2013). 'Monetary Transmission Mechanism in East African Community: An Empirical Investigation', IMF Working Paper no. 39/2013

5. Dungey, M. and Fry, R. (2009). 'The identification of fiscal and monetary policy in a structural VAR', Economic Modelling, 26(6): 1147-1160.

6. Gujarati (2004), "Basic Econometrics", 4th edition, New York: The McGraw-Hill

7. Kim, S. and N. Roubini. 2000. "Exchange Rate Anomalies in the Industrial Countries: A Solution with a Structural VAR Approach.” Journal of Monetary Economics 45(3):561-586.

8. Meltzer Allan H., 1995, 'Monetary, Credit and (Other) Transmission Processes: A Monetarist Perspective', Journal of Economic Perspectives, Vol. 9 (4), pp. 49-72

9. Mengesha, L. G., \& Holmes, M. J. (2013). Monetary policy and its transmission mechanisms in Eritrea. Journal of Policy Modeling, 35(5), 766-780

10. Mishra, P., \&Montiel, P. (2012). How effective is monetary transmission in low-income countries? A survey of the empirical evidence (IMF Working Paper: WP/12/143). Washington, DC: International Monetary Fund.

11. Mishkin, F. S. (1995). 'Symposium on the monetary transmission mechanism', The Journal of Economic Perspectives, 9(4): $3-10$

12. NBE (National Bank of Ethiopia) (2017/18). Annual Report 2017/18. Addis Ababa: NBE.

13. Tang, H. C. (2006), "The Relative Importance of Monetary Policy Transmission Channels in Malaysia", CAMA Working Paper Series, No.23

14. National Bank of Ethiopia(2009), "NBE’s Monetary Policy Framework", Economic Research and Monetary Policy Process, NBE, Addis Ababa, Ethiopia

15. Nuru (2013), “An Empirical Investigation on Monetary Policy Transmission Mechanism in Ethiopia”, Research Paper in Economics Department of Addis Ababa University, Ethiopia

16. Raghavan, M., Silvapulle, P., \&Athanasopoulos, G. (2012). Structural VAR models for Malaysian monetary policy analysis during the pre- and post-1997 Asian crisis periods. Applied Economics, 44(29), 3841-3856.

17. Sims, C. A. (1980), "Macroeconomics and Reality", Econometrica, 48 (1) pp 1-48

18. Tang, H. C. (2006), "The Relative Importance of Monetary Policy Transmission Channels in Malaysia”, CAMA Working Paper Series, No.23

19. Aleem, A. (2010), "Transmission mechanism of monetary policy in India”, Journal of Asian Economics, Vol.21 No.2, pp.186-197.

20. Perera, A., and Wickramanayake, J. (2013), "Monetary Transmission in The Emerging Country Context: The Case of Sri Lanka”, Central Bank of Sri Lanka International Research Conference-2013, pp.1-80.

21. Wooldridge (2013), "Introductory Economics: A modern Approach", Cenage Learning, 5th edition, Michigan State University, United States. 